\title{
Pilot scale production and characterization of pectinase enzyme from Aspergillus niger
}

\author{
- KAMLESh KumAR MEENA* AND V.N. PAWAR \\ Department of Food Science and Technology, College of Agriculture Technology, Marathwada Krishi Vidyapeeth, PARBHANI \\ (M.S.) INDIA \\ E-mail : kamlesh_foodtech@yahoo.co.in \\ *Author for Correspondence \\ Research chronicle : Received : 18.12.2014; Revised : 07.04.2015; Accepted : 20.04.2015
}

SUMMARY :

Food grade pectinases from A. niger, are predominantly used as processing aids in industries. In present investigation, efforts were made to standardize pilot scale production of pectinase enzyme by Aspergillus niger. The crude enzyme was studied for its kinetics to optimize substrate concentration and processing parameters on the basis of polygalacturonic activity. Km was determined by measuring reaction velocities while temperature and $\mathrm{pH}$ range was standardized on the basis of activity of polygalacturonase. The results revealed that $\mathrm{km}$ was observed to be $2.43 \mathrm{mg} / \mathrm{ml}$. It was found that the enzyme exhibited maximum activity at $40^{\circ} \mathrm{C}$. Increase in temperature above $40^{\circ} \mathrm{C}$, the enzyme activity was affected negatively coupled with gradual reduction. The polygalacturonase recorded optimum activity $(5.78 \mu \mathrm{mol} / \mathrm{ml} / \mathrm{min})$ at $\mathrm{pH} 4.5$ and $9 \mathrm{mg} / \mathrm{ml}$ substrate concentration, respectively enzyme activity. Linear increase with in increased in substrate concentration, exhibited by pectinase is in agreement with the results recorded by earlier scientists.

KEY WORDS : Pectinase, Aspergillus niger, Kinetics, Polygalacturonase activity, Enzyme

How to cite this paper : Meena, Kamlesh Kumar and Pawar, V.N. (2015). Pilot scale production and characterization of pectinase enzyme from Aspergillus niger. Internat. J. Proc. \& Post Harvest Technol., 6 (1) :14-18. 